\title{
Assessment of Inhalation Technique in Clinical and Functional Control of Asthma and Chronic Obstructive Pulmonary Disease
}

\author{
Avaliação da Técnica Inalatória no Controlo Clínico e Funcional da Asma e \\ Doença Pulmonar Obstrutiva Crónica
}

Tiago MARICOTO ${ }^{1}$, Luís Vaz RODRIGUES ${ }^{2}$, Gilberto TEIXEIRA², Carla VALENTE² ${ }^{2}$ Lília ANDRADE $^{2}$, Alcina SARAIVA $^{2}$ Acta Med Port 2015 Nov-Dec;28(6):702-707

\section{ABSTRACT}

Introduction: Chronic obstructive pulmonary disease and asthma affect almost 300 million individuals. Inhaled therapy is often associated with technical errors reducing efficacy and compliance.

Objective: To evaluate the inhalation technique and its relation with clinical and functional control in asthma and chronic obstructive pulmonary disease.

Material and Methods: Analytical cross-sectional study including patients with asthma and chronic obstructive pulmonary disease treated with any type of inhaler device. Demographic data and inquiry about previous teaching of inhalation technique were collected in all participants. Inhalation technique was evaluated in: Step 1 - device activation; Step 2 - previous expiration; Step 3 - inspiration; Step 4 - end inspiratory pause. Clinical control was assessed from the questionnaires Asthma Control Test, Control of Allergic Rhinitis and Asthma Test, modified Medical Research Council and Chronic Obstructive Pulmonary Disease Assessment Test. Spirometric evaluation was performed in all participants.

Results: From a total of 62 subjects, $74.19 \%$ made at least one error, mainly during step 2 (53.2\%). Previous education on inhalation technique was associated with lower number of errors $(p=0.014)$. There was no association between number of errors and age $(p=0.321)$, years of diagnosis $(p=0.119)$ or spirometric evaluation $(p>0.05)$. In asthma an association was found between number of errors and Asthma Control Test $(p=0.032)$ and Control of Allergic Rhinitis and Asthma Test $(p=0.008)$.

Discussion and Conclusion: Teaching inhalation technique has a positive impact on its future performance. Most patients make mistakes, affecting clinical control in asthma, although in chronic obstructive pulmonary isease no relation was found. This is an ongoing work that aims to reevaluate inhalation technique after patients' education and its further impact.

Keywords: Administration, Inhalation; Asthma; Nebulizers and Vaporizers; Pulmonary Disease, Chronic Obstructive.

\section{RESUMO}

Introdução: A doença pulmonar obstrutiva crónica e a asma afectam quase 300 milhões de indivíduos em todo o mundo. A terapêutica inalatória associa-se frequentemente a erros na técnica realizada reduzindo a eficácia e adesão.

Objectivo: Avaliar a técnica inalatória e sua relação com o controlo clínico e funcional em asma e doença pulmonar obstrutiva crónica. Material e Métodos: Estudo transversal analítico incluindo doentes com asma e doença pulmonar obstrutiva crónica medicados com dispositivos inalatórios. Recolheram-se dados demográficos e existência de ensino prévio da técnica. Avaliou-se a técnica inalatória em: Passo 1 - expiração prévia; Passo 2 - activação do dispositivo; Passo 3 - inspiração; Passo 4 - apneia final. O controlo clínico avaliou-se com os questionários Asthma Control Test, Control of Allergic Rhinitis and Asthma Test, modified Medical Research Council e Chronic Obstructive Pulmonary Disease Assessment Test. Todos os participantes realizaram avaliação espirométrica.

Resultados: Obtiveram-se 62 participantes, dos quais $74,19 \%$ cometeram pelo menos um erro na inalação, principalmente na expiração prévia $(53,2 \%)$. A existência prévia de ensino da técnica associou-se a menor $n^{\circ}$ de erros $(p=0,014)$. Não houve associação entre $\mathrm{n}^{\circ}$ de erros e idade $(p=0,321), \mathrm{n}^{\circ}$ de anos de diagnóstico $(p=0,119)$ ou avaliação espirométrica $(p>0,05)$. Na asma encontrou-se associação entre menor número de erros e Asthma Control Test $(p=0,032)$ e Control of Allergic Rhinitis and Asthma Test $(p=0,008)$. Discussão e Conclusão: $O$ ensino da técnica inalatória melhora o seu desempenho futuro. A maioria dos doentes comete erros afectando o controlo clínico na asma, apesar de na doença pulmonar obstrutiva crónica não se verificar nenhuma associação. Este trabalho encontra-se a decorrer procurando reavaliar os doentes após o ensino da técnica e verificar o seu impacto subsequente.

Palavras-chave: Administração por Inalação; Asma; Doença Pulmonar Obstrutiva Crónica; Nebulizadores e Vaporizadores.

\section{INTRODUCTION}

Asthma and chronic obstructive pulmonary disease (COPD) are respiratory disorders with a high prevalence worldwide. It is estimated that asthma affects about 6.8 to $10 \%$ of the Portuguese population ${ }^{1-2}$ and only $57 \%$ of these are controlled. ${ }^{3}$ Its global prevalence may reach $18 \%{ }^{4}$ and in 2004 the World Health Organization (WHO) estimated a total of 234 million individuals affected. ${ }^{5}$

In 2011, according to the GOLD study and the National Centre for Respiratory Diseases it was estimated that the

prevalence of COPD can reach $14.2 \%$ in the Portuguese population over 40 years ${ }^{2,6}$ and the $\mathrm{WHO}$ pointed to 64 million people affected in 2004 worldwide. ${ }^{5}$

Inhaled therapy due to its specificity is the most effective modality for these diseases. Several types of inhalers are available in the market with different inhalation techniques and different specifications for each other. These differences often generate confusion in patients with consequent errors in the technique performance,

1. Medicina Geral e Familiar. Unidade de Cuidados de Saúde Primários Aveiro I. Aveiro. Portugal.

2. Departmento de Pneumologia. Hospital Central do Baixo Vouga. Aveiro. Portugal.

$\bowtie$ Autor correspondente: Tiago Maricoto. tiago.maricoto@gmail.com

Recebido: 16 de Outubro de 2014 - Aceite: 25 de Agosto de 2015 | Copyright @ Ordem dos Médicos 2015 
leading to reduced efficacy, increased side effects and poor adherence. Up to $76 \%$ of patients show some error in the inhalation technique ${ }^{7}$ and in Portugal some studies showed several difficulties in handling devices either by patients ${ }^{8}$ or by doctors. ${ }^{9}$ Growing evidence shows that educating and reviewing the technique with the patients have a positive impact on adherence, quality of life and control of asthma and COPD. ${ }^{10-12}$ Several international organizations reinforce the need for clinicians to master knowledge about different types of inhalers available in the market and appropriate inhalation techniques for each one, in order to assess at each patient if the technique is appropriate to his particular profile. ${ }^{13}$ The Portuguese Directorate General for Health recommends, in its standard clinical guideline for control of asthma, that the inhaler technique should be reviewed by health professionals at each visit with the patient. ${ }^{14}$

Our objective was to evaluate the inhalation technique and its relation with clinical and functional control in asthma and COPD.

\section{MATERIAL AND METHODS}

This analytical cross-sectional study was conducted at the Pulmonology Department, Hospital Central do Baixo Vouga, Portugal, in the first semester of 2013. Patients with an established diagnosis of asthma and COPD that were treated with at least one inhaler device including dry powder devices (DPI) and metered dose pressurized devices (pMDI), with or without a spacer device, were included by convenience sampling. Children up to 12 years and patients receiving domiciliary nebulizers were excluded. The variables under study were:

- Demographic data [age, gender];

- Clinical Control [numerical score in validated questionnaires in Portuguese: Asthma Control Test (ACT), ${ }^{15}$ Control of Allergic Rhinitis and Asthma Test (CARAT), ${ }^{16}$ modified Medical Research Council $(\mathrm{mMRC})^{17}$ and COPD Assessment Test (CAT)] $]^{18}$;

- Functional Control [numeric value as a percentage

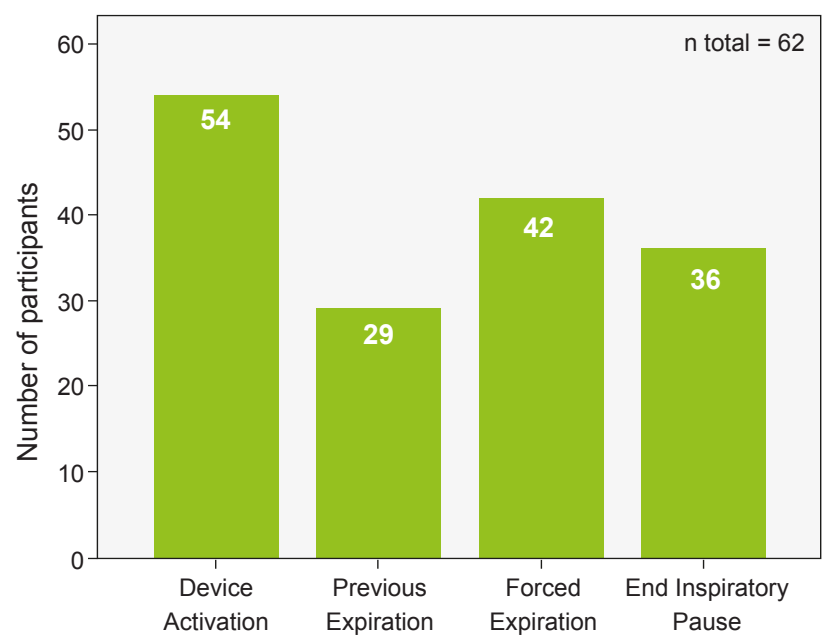

Figure 1 - Number of participants who performed the inhalation technique properly, for each defined stage of the predicted value: Forced expiratory volume in 1 second (FEV1); Peak expiratory flow (PEF); Forced vital capacity (FVC); FEV1/FVC ratio; Forced expiratory volume between $25 \%$ and $75 \%$ of lung capacity (FEV25$75)$ and peripheral oxygen saturation $\left(\mathrm{SpO}_{2}\right)$; obtained by spirometry and pulse oximetry];

- Existence of previous training of the inhaler technique by a health professional (doctor, nurse or pharmacist);

- Years after diagnosis;

- Number of steps of inhalation technique correctly performed by the participant [4 steps were defined: Step 1 - Device activation (assessed the fulfillment of the main technical features and recommendations of the manufacturer of each device); Step 2 - Previous expiration; Step 3 - Inspiration (on DPI was considered to be correct a fast and vigorous inhalation and on pMDI a slow and steady inhalation; on pMDI coupled to an expander chamber were considered correct either a single slow and steady inhalation or a tidal volume inhalation of 5 to 10 cycles of breathing, dismissing end inspiratory pause; the exception was applied to Jetspacer ${ }^{\circledR}$ chamber that should only be used on single inhalation); Step 4 - End inspiratory pause of 5 to 10 seconds].

The inhalation technique was evaluated always by the same physician and using placebo or the patient's own devices. Clinical Control was assessed before inhalation technique evaluation. All variables were evaluated at the same moment.

Data were treated in analytical statistics for comparison between quantitative variables and for association between qualitative variables, with parametric and non-parametric tests (ANOVA, Kruskal-Wallis and Fisher's exact test), through the computer system Microsoft Office Excel $2010^{\circledR}$ and IBM SPSS Statistics $20^{\circledR}$. The normality distribution of quantitative variables was tested using KolmogorovSmirnov test and all subgroups were tested to ensure the homogeneity of variances, in order to use parametric tests.

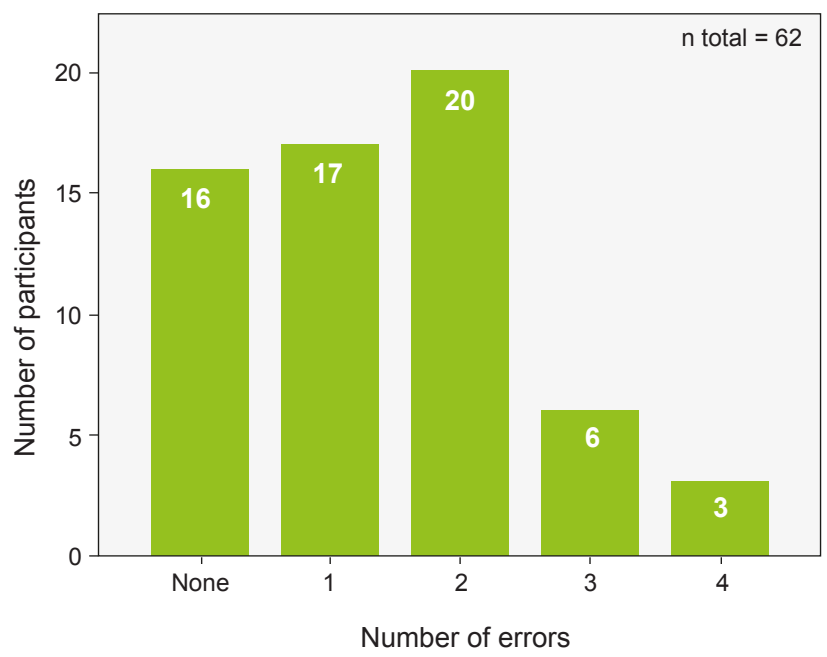

Figure 2 - Distribution of all participants, according to the number of errors made in inhalation technique 
Table 1 - Number of errors in inhalation technique according to previous training sessions

\begin{tabular}{lccccc}
\hline & & Previous training & Yes & \\
& & No & 3 & 13 & 16 \\
& None & 1 & 7 & 10 & 17 \\
Number of errors committed in inhalation & 2 & 10 & 10 & 1 & 20 \\
& 3 & 5 & 0 & 3 \\
Total & 4 & 3 & 34 & 62 \\
\hline
\end{tabular}

$p=0.014^{*}$

${ }^{*}$ Fisher's Exact test.

Table 2 - Results obtained for each variable, according to the number of errors committed

\begin{tabular}{|c|c|c|c|c|c|c|}
\hline \multirow{2}{*}{ Variable } & \multicolumn{5}{|c|}{ Number of errors committed in inhalation } & \multirow{2}{*}{$p$ value } \\
\hline & None & 1 & 2 & 3 & 4 & \\
\hline \multicolumn{7}{|l|}{ Number of patients: } \\
\hline - Asthma & 10 & 8 & 12 & 2 & 3 & $\mathrm{NA}^{\dagger}$ \\
\hline - COPD & 6 & 9 & 8 & 4 & 0 & $\mathrm{NA}^{\dagger}$ \\
\hline Mean age ${ }^{\S}$ (years) & $\begin{array}{c}47.88 \\
(17.84)\end{array}$ & $\begin{array}{c}54.65 \\
(23.57)\end{array}$ & $\begin{array}{c}60.15 \\
(17.02)\end{array}$ & $\begin{array}{c}61.17 \\
(16.79)\end{array}$ & $\begin{array}{l}63.33 \\
(9.61)\end{array}$ & $0.357^{\ddagger}$ \\
\hline Years of diagnosis $\$$ & $\begin{array}{c}10.06 \\
(11.15)\end{array}$ & $\begin{array}{c}13.88 \\
(15.53)\end{array}$ & $\begin{array}{c}17.35 \\
(15.32)\end{array}$ & $\begin{array}{c}18.67 \\
(18.28)\end{array}$ & $\begin{array}{c}22.00 \\
(25.24)\end{array}$ & $0.602^{\ddagger}$ \\
\hline \multicolumn{7}{|c|}{ Respiratory function ${ }^{\S}$ (Asthma and COPD patients together) } \\
\hline - FEV1* & $\begin{array}{c}73.56 \\
(24.06)\end{array}$ & $\begin{array}{c}68.65 \\
(29.35)\end{array}$ & $\begin{array}{c}67.75 \\
(25.41)\end{array}$ & $\begin{array}{c}55.00 \\
(29.85)\end{array}$ & $\begin{array}{c}82.00 \\
(34.70)\end{array}$ & $0.643^{\ddagger}$ \\
\hline - FEV $25-75^{*}$ & $\begin{array}{c}49.06 \\
(25.18)\end{array}$ & $\begin{array}{c}49.06 \\
(37.97)\end{array}$ & $\begin{array}{c}48.78 \\
(41.14)\end{array}$ & $\begin{array}{c}50.00 \\
(45.93)\end{array}$ & $\begin{array}{c}66.67 \\
(58.05)\end{array}$ & $0.882^{\ddagger}$ \\
\hline - FEV1/FVC & $\begin{array}{c}71.31 \\
(12.93)\end{array}$ & $\begin{array}{c}70.82 \\
(17.55)\end{array}$ & $\begin{array}{c}69.47 \\
(17.42)\end{array}$ & $\begin{array}{c}75.67 \\
(19.67)\end{array}$ & $\begin{array}{c}81.33 \\
(14.84)\end{array}$ & $0.731^{\ddagger}$ \\
\hline - $\mathrm{PEF}^{*}$ & $\begin{array}{c}71.06 \\
(18.40)\end{array}$ & $\begin{array}{c}69.65 \\
(26.93)\end{array}$ & $\begin{array}{c}64.15 \\
(23.91)\end{array}$ & $\begin{array}{c}48.67 \\
(28.56)\end{array}$ & $\begin{array}{c}74.67 \\
(30.14)\end{array}$ & $0.286^{\ddagger}$ \\
\hline \multicolumn{7}{|c|}{ Clinical asthma control $\S$} \\
\hline - CARAT & $\begin{array}{l}14.50 \\
(2.72)\end{array}$ & $\begin{array}{l}12.50 \\
(5.95)\end{array}$ & $\begin{array}{l}11.50 \\
(4.42)\end{array}$ & $\begin{array}{c}8.00 \\
(7,07)\end{array}$ & $\begin{array}{c}6.00 \\
(4.58)\end{array}$ & $0.091^{\ddagger}$ \\
\hline - ACT & $\begin{array}{l}21.50 \\
(2.07)\end{array}$ & $\begin{array}{l}19.88 \\
(5.46)\end{array}$ & $\begin{array}{l}18.33 \\
(4.72)\end{array}$ & $\begin{array}{l}14.00 \\
(5.66)\end{array}$ & $\begin{array}{l}11.33 \\
(6.43)\end{array}$ & $0.025^{\ddagger}$ \\
\hline \multicolumn{7}{|c|}{ Clinical COPD control ${ }^{\S}$} \\
\hline - CAT & $\begin{array}{l}17.67 \\
(9.99)\end{array}$ & $\begin{array}{l}18.78 \\
(9.73)\end{array}$ & $\begin{array}{l}23.75 \\
(6.82)\end{array}$ & $\begin{array}{c}24.75 \\
(16.88)\end{array}$ & $\mathrm{NA}^{\dagger}$ & $0.371^{\ddagger}$ \\
\hline - $\mathrm{mMRC}$ & $\begin{array}{c}1.67 \\
(1.34)\end{array}$ & $\begin{array}{c}1.78 \\
(1.20)\end{array}$ & $\begin{array}{c}2.38 \\
(1.06)\end{array}$ & $\begin{array}{c}2.75 \\
(1.89)\end{array}$ & $\mathrm{NA}^{\dagger}$ & $0.461^{\#}$ \\
\hline
\end{tabular}




\section{RESULTS}

Sixty two participants were recruited, with a mean age of 55.73 years $( \pm 19.21)$, thirty seven $(59.7 \%)$ men and twenty five $(40.3 \%)$ women. Thirty five $(56.5 \%)$ had asthma and twenty seven (43.5\%) had COPD.

Considering all, $55 \%$ had received previous education by other healthcare professional.

Fig. 1 shows the number of participants who performed each step correctly (device activation, previous expiration, inspiration and the end inspiratory pause), and Fig. 2 shows the number of participants according to the quantity of errors committed. It was observed that $74.19 \%$ of individuals committed at least one error, the most common was the lack of previous expiration $(53.2 \%)$. The previous teaching of inhaler technique was significantly associated with a lower number of committed errors $(p=0.014$, Fisher's Exact test) (Table 1). Table 2 summarizes the results obtained from the studied variables. There was no association between the number of errors and: age
( $p=0.357$, Kruskal-Wallis); number of years of diagnosis ( $p=0.602$, Kruskal-Wallis); \%FEV1, \%FEV25 - 75, FEV1/ FVC, \%FVC or \%PEF ( $p>0.05$, Kruskal-Wallis). Even when analyzing COPD and asthma patients separately, there were no significant associations between number of errors and functional control ( $p>0.05$, Kruskal-Wallis). Fig.s 3 and 4 show the relationship between the number of errors and the score obtained in the questionnaires for clinical evaluation, either for COPD or asthma, respectively. In patients with asthma there was an association between lower number of errors and better clinical control, either by the ACT becoming significant from three errors committed with a mean difference of $7.5( \pm 3.5)$ points $(p=0.032$, ANOVA), or by CARAT becoming significant at four errors with an average difference of $8.5( \pm 3)$ points $(p=0.008$, ANOVA). In patients with COPD, there was no significant relationship between clinical control and the quality of the inhalation technique.

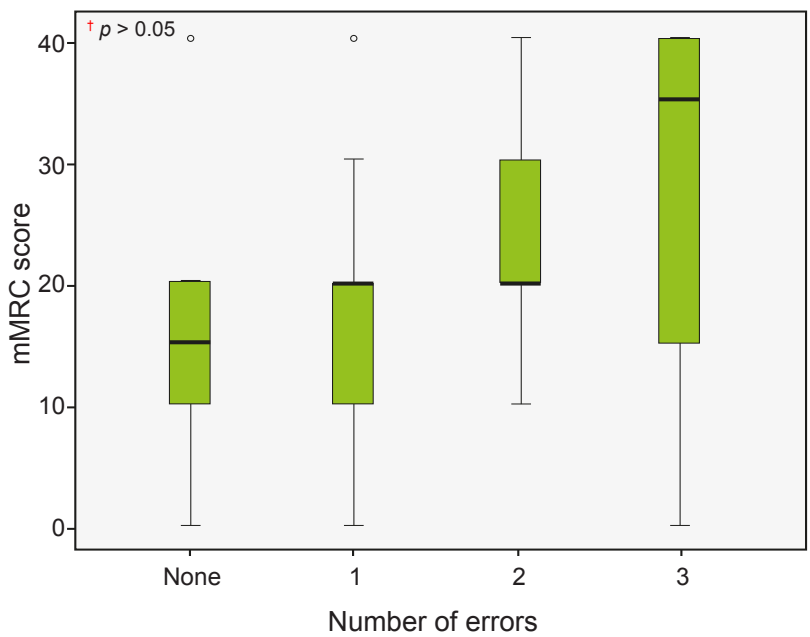

Figure 3 - Relationship between the number of errors and the score obtained in CAT and mMRC questionnaires in COPD patients CAT: COPD Assessment Test; mMRC: modified Medical Research Council; ${ }^{*}$ Kruskal-Wallis test; ${ }^{\dagger}$ Fisher's Exact test.
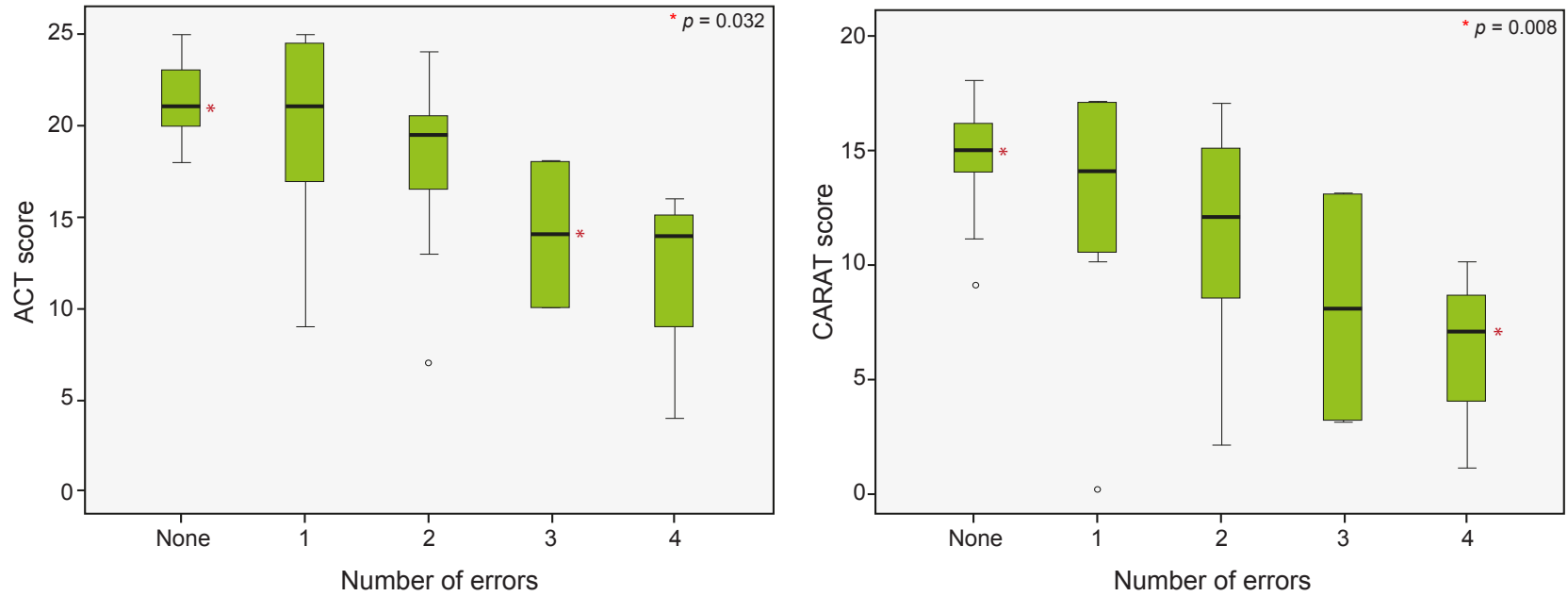

Figure 4 - Relationship between the number of errors and the score obtained in ACT and CARAT questionnaires in asthma patients ACT: Asthma Control Test; CARAT: Control of Allergic Rhinitis and Asthma Test; * ANOVA test. 


\section{DISCUSSION AND CONCLUSION}

These results show that most patients make mistakes in the inhalation technique and this phenomenon does not seem to be associated with age or even the number of years of diagnosis. Despite having not found a statistically significant relationship between the number of errors and age, it was clear that younger patients made fewer mistakes, which may be due to a higher literacy. The low sample size of this study may have compromised the statistical power of these findings, underestimating this effect. Actually, the factor mostly associated with a lower number of errors was the previous existence of inhalation technique education. This finding is consistent with other studies previously published which highlight the utility of continuous and systematic review of inhalation technique among patients in consultation..$^{19-22}$ Thus, it seems that the establishment of a query surveillance program set for asthma and COPD in Primary Health Care could be presented as one solution to this reality, allowing coverage of a greater number of patients in the general population. Although different approach strategies can be used, ${ }^{23}$ more studies are needed to determine the effectiveness of surveillance programs covering practical aspects, such as the time required in each medical visit for the review and the teaching of technique to the patient, thereby promoting adherence. Other health professionals, such as physicians in other areas of specialty, respiratory therapists, nurses or pharmacists may even be involved in the education process for patients. ${ }^{24-26}$ Future work should focus on the effectiveness of the review at each visit and on the knowledge and training of health professionals in this field.

The results of this study also show that a good inhalation technique is associated with a better clinical control in asthma. This effect is related to the number of errors, and it was found that the presence of three or more errors was significantly associated with poorer clinical scores. In patients with COPD no statistical significance was found, however it appears that the clinical control seems to get worse as more mistakes are committed in inhalation.
This may be due to the low sample size, as said above, or even due to pathophysiological differences between the two diseases. The most effective reversibility of airway obstruction in asthma may justify a larger difference in the objective perception of improvement in respiratory symptoms by patients when the devices are used correctly.

Both in asthma and COPD, no objective relationship between the results of lung function assessment and the number of errors was found. This may be due to several underlying bias. First of all the small sample size, limiting the statistical power of any differences in functional parameters, therefore larger samples may highlight these differences; and also this study did not assess the individual progress of each patient. Different individuals were compared showing different pathophysiological characteristics, particularly in relation to the number of years of evolution and to the clinical and functional severity of the disease. This work is still ongoing and aims to reevaluate the inhalation technique of each participant after the individual teaching and its optimization, and to check if there is, therefore, an impact on the clinical and functional scores.

\section{PROTECTION OF HUMANS AND ANIMALS}

The authors declare that the procedures were followed according to the regulations established by the Clinical Research and Ethics Committee and to the Helsinki Declaration of the World Medical Association.

\section{DATA CONFIDENTIALITY}

The authors declare having followed the protocols in use at their working center regarding patient's data publication.

\section{CONFLICTS OF INTEREST}

The authors state no conflict of interests and have received no payment to perform this work.

\section{FUNDING SOURCES}

No subsidies or grants contributed to this work.

\section{REFERENCES}

1. Sá-Sousa A, Morais-Almeida M, Azevedo LF, Carvalho R, Jacinto T, Todo-Bom A, et al. Prevalence of asthma in Portugal - The Portuguese National Asthma Survey. Clin Transl Allergy. 2012;2:15

2. de Araújo AT. Relatório do Observatório Nacional das Doenças Respiratórias - Desafios e oportunidades em tempos de crise [e-book]. Fundação Portuguesa do Pulmão. 2011. [Consulted 2015 Feb 20]. Available from: http://www.ondr.pt.

3. Direç̧ão Geral de Saúde. I Inquérito Nacional sobre Asma. INASma Sumário do Inquérito Nacional de Controlo da Asma. 2010. [Consulted 2015 Feb 20]. Available from: http://www.dgs.pt.

4. Reddel H, Barnes P, Barnes N, Baterman ED, Becker A, Bel E, et al. Global strategy for asthma management and prevention. Revised 2014. Global initiative for asthma. [Consulted 2015 Feb 20]. Available from: http://www.ginasthma.org.

5. World Health Organization. The global burden of disease: 2004 update. 2008. [Consulted 2015 Feb 20]. Available from: http://www.who.int.

6. Bárbara C, Rodrigues $\mathrm{F}$, Diasa $\mathrm{H}$, Cardoso J, Almeida J, Matos MJ, et al. Prevalência da doença pulmonar obstrutiva crónica em Lisboa, Portugal: estudo Burden of Obstructive Lung Disease. Rev Port Pneumol. 2013;19:96-105.

7. Molimard M, Raherison C, Lignot S, Depont F, Abouelfath A, Moore N Assessment of handling of inhaler devices in real life: an observational study in 3811 patients in primary care. J Aerosol Med. 2003;16:249-54.

8. Morais A, Rocha L, Hespanhol V. Estudo comparativo do manuseamento dos vários dispositivos de inalação utilizados em Portugal. Rev Port Pneumol. 2001; VII:9-24.

9. Silveira $P$, Rocha $L$, Ferreira J. Técnicas de medicação inalatória: saberão os clínicos utilizar os dispositivos inalatórios?. Rev Port Imunoalergol. 1998;5:37-42.

10. Lavorini F, Magnan A, Dubus JC, Voshaarg T, Corbetta L, Broeders M, et al. Effect of incorrect use of dry powder inhalers on management of patients with asthma and COPD. Respir Med. 2008;102:593-604.

11. Giraud V, Allaert FA, Roche N. Inhaler technique and asthma: feasability and acceptability of training by pharmacists. Respir Med. 2011;105:1815-22.

12. Göriş $S$, Taşci $S$, Elmali $F$. The effects of training on inhaler technique and quality of life in patients with COPD. J Aerosol Med Pulm Drug Deliv. 2013;26:336-44

13. Laube BL, Janssens HM, de Jongh FH, Devadason SG, Dhand R, Diot $\mathrm{P}$, et al. European Respiratory Society; International Society for Aerosols 
in Medicine. What the pulmonary specialist should know about the new inhalation therapies. Eur Respir J. 2011;37:1308-31.

14. Direcção-Geral da Saúde. Abordagem e controlo da asma. 2011 [Updated 2012]. Direcção Geral de Saúde. Norma número 016/2011. [Consulted 2015 Feb 20]. Available from: http://www.dgs.pt.

15. Roxo JP, Ponte EV, Ramos DC, Pimentel L, D’Oliveira Júnior A, Cruz AA. Validação do teste de controlo da asma em português para uso no Brasil. J Bras Pneumol. 2010;36:159-66.

16. Fonseca JA, Nogueira-Silva L, Morais-Almeida M, Azevedo L, SáSousa A, Branco-Ferreira $M$, et al. Validation of a questionnaire (CARAT10) to assess rhinitis and asthma in patients with asthma. Allergy. 2010;65:1042-8.

17. KovelisD, Segretti NO, Probst VS, Lareau SC, Brunetto AF, Pitta F. Validation of the modified pulmonary functional status and dyspnea questionnaire and the medical research council scale for use in Brazilian patients with chronic obstructive pulmonary disease. J Bras Pneumol. 2008;34:1008-18.

18. Silva GP, Morano MT, Viana CM, Magalhães $C B$, Pereira ED. Portuguese-language version of the COPD Assessment Test: validation for use in Brazil. J Bras Pneumol. 2013;39:402-8.

19. Press VG, Arora VM, Shah LM, Lewis SL, Charbeneau J, Naureckas $E T$, et al. Teaching the use of respiratory inhalers to hospitalized patients with asthma or COPD: a randomized trial. J Gen Intern Med. 2012;27:1317-25.

20. Margolis A, Young H, Lis J, Schuna A, Sorkness CA. A telepharmacy intervention to improve inhaler adherence in veterans with chronic obstructive pulmonary disease. Am J Health Syst Pharm. 2013;70:1875-
6.

21. Ammari WG, Chrystyn $\mathrm{H}$. Optimizing the inhalation flow and technique through metered dose inhalers of asthmatic adults and children attending a community pharmacy. J Asthma. 2013;50:505-13.

22. Leiva-Fernández F, Leiva-Fernández J, Zubeldia-Santoyo F, GarcíaRuiz A, Prados-Torres D, Barnestein-Fonseca P. Efficacy of two educational interventions about inhalation techniques in patients with chronic obstructive pulmonary disease (COPD). TECEPOC: study protocol for a partially randomized controlled trial (preference trial) Trials. 2012;13:64.

23. Bosnic-Anticevich SZ, Stuart M, Mackson J, Cvetkovski B, Sainsbury $\mathrm{E}$, Armour C. Development and evaluation of an innovative model of inter-professional education focused on asthma medication use. BMC Med Educ. 2014;14:72

24. Bereznicki BJ, Peterson G, Jackson S, Walters EH, George J, Stewart $\mathrm{K}$, et al. Uptake and effectiveness of a community pharmacy intervention programme to improve asthma management. J Clin Pharm Ther. 2013;38:212-8.

25. Upton J, Fletcher M, Madoc-Sutton $H$, Sheikh A, Caress AL, Walker $\mathrm{S}$. Shared decision making or paternalism in nursing consultations? A qualitative study of primary care asthma nurses' views on sharing decisions with patients regarding inhaler device selection. Health Expect. 2011;14:374-82.

26. Takemura M, Mitsui K, Ido M, Matsumoto M, Koyama M, Inoue D, et al. Impact of a network system for providing proper inhalation technique by community pharmacists. J Asthma. 2012;49:535-41. 


\section{Assessment of Inhalation Technique in Clinical and Functional Control of Asthma and Chronic Obstructive Pulmonary Disease}

Acta Med Port 2015:28:702-707

Publicado pela Acta Médica Portuguesa, a Revista Científica da Ordem dos Médicos

Av. Almirante Gago Coutinho, 151

1749-084 Lisboa, Portugal.

Tel: +351218428215

E-mail: submissao@actamedicaportuguesa.com

www.actamedicaportuguesa.com

ISSN:0870-399X | e-ISSN: 1646-0758

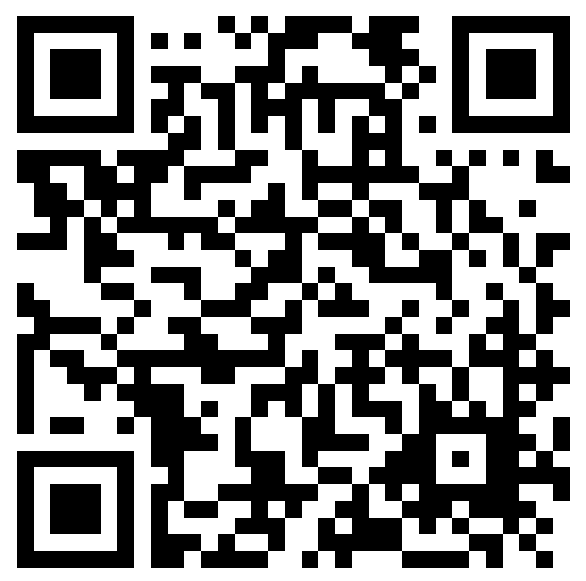

ACTA MÉDICA

PORTUGUESA 